\title{
FINANCIAL VULNERABILITY AND INCOME INEQUALITY: NEW EVIDENCE FROM OECD COUNTRIES
}

\author{
Nicholas Apergis $^{1}$ \\ ${ }^{1}$ University of Piraeus, Piraeus, Greece. Email: napergis@unipi.gr
}

\begin{abstract}
This study explores, for the first time, how financial vulnerability affects income inequality across OECD countries, from 1990 to 2015. The empirics use a new financial vulnerability index constructed by Adrian and Duarte (2016). Through the methodology of their modeling approach, panel GARCH and GMM methods, the findings indicate that financial vulnerability exerts a negative impact on income equality conditions. The results survive certain definitions of income inequality and corruption, while they highlight the importance of financial stability conditions, with potential further repercussions to the real economy.
\end{abstract}

Keywords: Financial vulnerability; Income inequality; Panel country data.

JEL Classification: G20; D31; C33.

Article history:

Received : June 1, 2018

Revised : :September 10, 2018

Accepted : : September 11, 2018

Available online : January 30, 2019

https://doi.org/10.21098/bemp.v21i3.945 


\section{INTRODUCTION}

The role of financial vulnerability is relevant to GDP growth, associated with risks to asset valuations (Adrian et al., 2015). This vulnerability includes the vulnerability of financial institutions. The financial system, especially after the 2008 Global Financial Crisis (GFC), has become increasingly fragile (Liu, 2012; Tropeano, 2013). Based on the financial fragility hypothesis, Minsky (1982) argues that the intrinsic characteristics of banking institutions make firms to face bankruptcy, with a negative effect on the real economy.

Furthermore, given the wide differences of income and wealth across the globe, as well as the role of the banking sector to provide access to credit (Jalilian and Kirkpatrick, 2002; Kai and Hamori, 2009), it is imperative to explore the relationship between financial vulnerability and income inequality. Beck et al. (2004) point out that income inequality and restricted access to finance can lead to reduced growth and welfare levels, while Mallick and Sousa (2013) investigate the impact of financial stress across Eurozone countries.

Financial vulnerability can be described either as banking failures and frictions, high asset price volatility, or a shortage of market liquidity. Financial vulnerability could also disrupt a country's payment system and, thus, to destabilize the entire economy. In other words, financial vulnerability can cause significant macroeconomic cost effects, including a deteriorating income distribution. Thus, mitigating financial vulnerabilities is essential for the macroeconomy, since these vulnerabilities cause changes in households and corporate sector's balance sheets, having potential impacts on the distribution of financial risk in the real economy.

Based on the above discussion, this paper investigates, to the best of our knowledge for the first time, how financial vulnerability affects income inequality across OECD countries, from 1990 to 2015. The analysis makes use of the financial vulnerability index constructed by Adrian and Duarte (2016). More specifically, they construct financial vulnerability from the National Financial Conditions Index (NFCI), provided by the Federal Reserve Bank of Chicago, which considers 105 financial, money, credit supply, and shadow bank indicators.

The paper is close to the strand of the literature that considers the role of the term spread in affecting the real economy. Estrella and Hardouvelis (1991) and Estrella and Mishkin (1998) show that term spreads forecast business cycles, while Gilchrist and Zakrajsek (2012), Lopez-Salido et al. (2017), and Krishnamurthy and Muir (2016) document that they forecast risks associated with GDP growth. Adrian et al. (2016) also provide evidence that stressful financial conditions increase GDP volatility. Philippon (2009), Gilchrist and Zakrajsek (2012), Krishnamurthy and Muir (2016), and Lopez-Salido et al. (2017) document that tighter financial conditions contribute to the contraction in output. Finally, the analysis considers the literature of the role of financial vulnerability in the entire economy, especially, after the 2008 financial crisis. This literature highlights that financial vulnerability indicates the presence of amplification mechanisms in relevance to leverage and asset valuations (Adrian et al., 2015; Aikman et al., 2015). 


\section{DATA AND METHODOLOGICAL MEASURES}

Annual data from 1990-2015 are considered, for a balanced panel of 35 OECD countries are used (Appendix A shows the countries included). The dependent variable is measured as income distribution, proxied by the Gini coefficient (GINI), which ranges from 0 (perfect income equality) to 1 (perfect income inequality). Data are sourced from the World Bank database. The control variable in focus is the index of financial vulnerability (FV) (Adrian and Duarte, 2016). This work provides the estimation of this index across OECD countries as a single panel. However, their index is available only for the U.S. In that sense, we make use of the same methodology and build a similar index for other OECD countries as well. Adrian et al. (2016) support the presence of downside risks for the GDP distribution affected by the course of financial conditions. The methodological extraction of the index is shown in Appendix B.

For the calculation of the financial vulnerability index, except the financial conditions measured above, we also obtain data on inflation, measured by the Consumer Price Index (for the euro countries, after 2000, prices are measured by the Harmonized Price index), income, proxied by real GDP (at constant 2010 prices), and central bank interest rates are proxied by the 3-month market rates. The analysis also uses the equity risk premium (ERP), measured as the excess return investors require to invest in stocks (Duarte and Rosa, 2014). It is based on a monthly basis. The analysis employs Morgan Stanley Capital International (MSCI) indexes for equity markets. All returns are on a monthly basis (expressed in US dollars). Risk free rates are 3-month bond yields from the International Financial Statistics (IFS) database. The vulnerability index is on a 10 -point scale $(0=$ total financial security, and 10= total financial vulnerability).

The remaining independent variables are: i) income per capita (PCI), ii) the enrolment ratio (ENROLL), concerning secondary level o education (\% gross), iii) the Polity index (POL) from the Polity IV database (Marshall and Jaggers, 2015); it illustrates the quality of institutions (Rodrik, 1996). The index is determined is ranging from -10 (pure autocracies) to 10 (pure democracies), iv) corruption (COR) which can adversely affect the economy (Mauro, 1997; Rose-Ackerman, 1999; among others). The ICRG corruption index is used, taking extreme values as $0=$ total corruption and $6=$ absence of corruption; it has been reversed so that $0=$ absence of corruption and $6=$ total corruption, $v$ ) population (POP) that accounts for the size of the country (Neumayer, 2003a,b); the larger the population of a country, the greater might be the need for financial access that will eventually affect income distribution, and finally, vi) government expenses (GOV), measured as percentages of GDP. The variables of population, school enrolment and government expenses as percentage of GDP are taken from the World Bank database.

\section{EMPIRICAL ANALYSIS}

A. Panel Unit Roots

First, we examine the unit root properties. Two second-generation panel unit root tests are employed; the Pesaran (2007) test, where the null hypothesis is a unit root and that by Smith et al. (2004), where all tests investigate the presence of a unit root. The results in Table 1 support the presence of a unit root across all variables; the exception is the variables of the Gini coefficient and the political variables. 
Table 1.

\section{Panel Unit Root Tests}

The table shows panel unit root tests. $\Delta$ denotes first differences. A constant is included in the Pesaran (2007) tests. Rejection of the null hypothesis indicates stationarity in at least one country. CIPS $*$ truncated CIPS test. Critical values for the Pesaran (2007) test are -2.40 at $1 \%,-2.22$ at $5 \%$, and -2.14 at $10 \%$, respectively. Both a constant and a time trend are included in the Smith et al. (2004) tests. Rejection of the null hypothesis indicates stationarity in at least one country. For both tests the results are reported at lag $=4$. The null hypothesis is that of a unit root. ${ }^{* * *}: \mathrm{p} \leq 0.01$.

\begin{tabular}{lcccccc}
\hline Variable & $\begin{array}{c}\text { Pesaran } \\
\text { CIPS }\end{array}$ & $\begin{array}{c}\text { Pesaran } \\
\text { CIPS* }\end{array}$ & $\begin{array}{c}\text { Smith et } \\
\text { al. } t \text {-test }\end{array}$ & $\begin{array}{c}\text { Smith et } \\
\text { al. LM- } \\
\text { test }\end{array}$ & $\begin{array}{c}\text { Smith et } \\
\text { al. max- } \\
\text { test }\end{array}$ & $\begin{array}{c}\text { Smith et } \\
\text { al. min- } \\
\text { test }\end{array}$ \\
\hline GINI & $-5.36^{* * *}$ & $-5.59^{* * *}$ & $-5.82^{* * *}$ & $23.15^{* * *}$ & $-6.14^{* * *}$ & $6.25^{* * *}$ \\
Financial Vulnerability & -1.27 & -1.35 & -1.31 & 3.14 & -1.40 & 1.29 \\
$\Delta$ Financial Vulnerability & $-5.42^{* * *}$ & $-5.64^{* * *}$ & $-6.35^{* * *}$ & $20.42^{* * *}$ & $-7.09^{* * *}$ & $7.16^{* * *}$ \\
Per Capita Income & -1.28 & -1.36 & -1.31 & 3.03 & -1.42 & 1.39 \\
$\Delta$ Per Capita Income & $-5.62^{* * *}$ & $-5.83^{* * *}$ & $-6.19^{* * *}$ & $20.84^{* * *}$ & $-6.57^{* * *}$ & $6.91^{* * *}$ \\
Enrollment Ratio & -1.30 & -1.38 & -1.36 & 2.91 & -1.39 & 1.43 \\
$\Delta$ Enrollment Ratio & $-5.53^{* * *}$ & $-5.77^{* * *}$ & $-5.60^{* * *}$ & $21.16^{* * *}$ & $-6.84^{* * *}$ & $7.11^{* * *}$ \\
Government Expenses & -1.27 & -1.36 & -1.33 & 3.01 & -1.38 & 1.45 \\
$\Delta$ Government Expenses & $-5.81^{* * *}$ & $-6.03^{* * *}$ & $-5.97^{* * *}$ & $21.79^{* * *}$ & $-6.40^{* * *}$ & $6.44^{* * *}$ \\
Population & -1.38 & -1.50 & -1.46 & 2.98 & -1.47 & 1.49 \\
$\Delta$ Population & $-5.61^{* * *}$ & $-5.84^{* * *}$ & $-5.72^{* * *}$ & $20.74^{* * *}$ & $-5.69^{* * *}$ & $5.93^{* * * *}$ \\
Polity Index & $-5.48^{* * *}$ & $-5.61^{* * *}$ & $-5.55^{* * *}$ & $20.52^{* * *}$ & $-5.38^{* * *}$ & $5.41^{* * *}$ \\
Corruption & -1.36 & -1.42 & -1.40 & 3.04 & -1.39 & 1.43 \\
$\Delta$ Corruption & $-5.62^{* * *}$ & $-5.79^{* * *}$ & $-5.73^{* * *}$ & $20.18^{* * *}$ & $-5.58^{* * *}$ & $5.74^{* * *}$ \\
\hline
\end{tabular}

\section{B. GARCH Estimates for GDP Growth}

Next, the analysis considers the methodology proposed by Adrian et al. (2016) who employ a GARCH model to estimate the conditional mean and variance of GDP growth:

$$
\begin{aligned}
& \mathrm{y}_{\mathrm{t}}=\gamma_{0}+\gamma_{1} \mathrm{y}_{\mathrm{t}-1}+\gamma_{2} \pi_{\mathrm{t}-1}+\gamma_{3} \mathrm{x}_{\mathrm{t}-1}+\sigma_{\mathrm{t}} \varepsilon_{\mathrm{t}} \\
& \ln \left(\sigma_{\mathrm{t}}\right)=\delta_{0}+\delta_{1} \mathrm{x}_{\mathrm{t}-1}
\end{aligned}
$$

where $x_{t}$ is the financial conditions index, and $y_{t}$ is the GDP growth rate. GDP depends on lagged inflation and GDP growth. The results are reported in Table 2 and they confirm those from Adrian and Duarte (2016) with estimates for the U.S.; they clearly indicate that the GDP distribution is left skewed, i.e., downside financial conditions lead to higher volatility and lower GDP growth. 
Table 2.

\section{GARCH GDP Conditional Mean and Volatility Estimates}

The table shows the GDP conditional mean and volatility estimates. Quarterly data, spanning the period 1990-2015 have been used. Figures in brackets denote $p$-values. Finally, ${ }^{*}$ and ${ }^{* *}$ denote statistical significance at the $10 \%$ and $5 \%$ levels, respectively.

\begin{tabular}{lcc}
\hline Parameter & Coefficients & $p$-value \\
\hline$\gamma_{0}$ & $1.714^{* *}$ & {$[0.05]$} \\
$\gamma_{1}$ & $0.078^{* *}$ & {$[0.05]$} \\
$\gamma_{2}$ & $0.036^{* *}$ & {$[0.05]$} \\
$\gamma_{3}$ & $-0.429^{* *}$ & {$[0.03]$} \\
$\delta_{0}$ & $0.254^{*}$ & {$[0.08]$} \\
$\delta_{1}$ & $0.052^{* *}$ & {$[0.03]$} \\
\hline
\end{tabular}

\section{GARCH Estimates for Equity Returns}

Next, we use a $\operatorname{GARCH}(1,1)$ model that estimates the mean and the volatility of the equity return. GARCH-type models have been primarily used in the literature on stock market volatility (Christofi and Pericli, 1999; Shin, 2005; Nikkinen, et al., 2008; Er and Fidan, 2013; among others). The analysis makes use of the overall stock market indexes and are computed as stock returns: $\ln \left(\mathrm{P}_{t}\right)-\ln \left(\mathrm{P}_{\mathrm{t}-1}\right), \mathrm{P}_{\mathrm{t}}$ is the overall price index.

Estimates for the model's parameters are presented in Table 3. The coefficients $\alpha$ and $\beta$ are both statistically significant. The fact that $\beta$ is relatively larger than $\alpha$ suggests that the conditional variance is primarily affected by the values of past conditional variance than by new disturbances. Once we get these estimates, then we can estimate the mean of the premium and its corresponding volatility.

Table 3.

\section{GARCH Results for Market Returns}

The table shows the GARCH results for market returns. Figures in brackets denote- $p$-values. Log-L is the log-likelihood function. Finally, ${ }^{* *}$ and ${ }^{* * *}$ denote statistical significance at the $5 \%$ and $1 \%$ levels, respectively.

\begin{tabular}{lcc}
\hline Parameter & Coefficients & $p$-value \\
\hline$\mu$ & $1.226^{* *}$ & 0.05 \\
$\omega$ & $0.364^{* *}$ & 0.03 \\
$\alpha$ & $0.238^{* * *}$ & 0.00 \\
$\beta$ & $0.594^{* * *}$ & 0.00 \\
$\log L$ & 895.409 & \\
\hline
\end{tabular}

\section{GMM Estimates of the Parameters of the Index}

The next step estimates the system of equations (B1) through (B4) in Appendix B through the linear is conducted within the General Method of Moments (GMM) approach (Arellano and Bond, 1991), which explicitly considers endogeneity issues. The results are in Table 4. The estimates are expected to calculate the vulnerability index from Equation (A7) in Appendix B. Higher values of the index illustrate higher financial vulnerability. 
Table 4.

GMM Estimates of the Parameters

The table shows the GMM estimates of the parameters of Equations (B1) to (B4).

\begin{tabular}{lc}
\hline Parameter & Coefficients \\
\hline$\gamma$ & 0.831 \\
$\xi$ & 0.314 \\
$\mu x$ & 0.0056 \\
$\rho x$ & 0.01 \\
$k$ & 0.0461 \\
$\beta$ & 0.98 \\
\hline
\end{tabular}

E. GMM Estimates Between Income Inequality and the Financial Vulnerability Index

Table 5 reports the empirical findings in relevance to the effect of the financial vulnerability index on income inequality. Column (1) reports the bivariate estimates, while column (2) reports the multivariate estimates (allowing all the other control variables to enter the regression). The findings document that financial vulnerability leads to worse income equality conditions. In economic terms, the estimates illustrate that a unit increase of the vulnerability index is associated with a seven and eight percentage points in the Gini coefficient, respectively.

The results also illustrate that income per capita leads to more income equality, while the same holds for the case of school enrolment. Similarly, higher government expenses lead to the same results, suggesting that public expenditure programs ensure greater income equality conditions (Roberts, 2003). Moreover, higher corruption scores lead to a worse income distribution, while higher measures of population worsen income equality, with findings being consistent with those by Gupta et al. (2002). An improved quality in the political regime (i.e., movements towards democracy) leads to a better income distribution. The diagnostics reject the null hypothesis of difference-in-Hansen tests, thus, supporting the validity of the instruments considered.

\section{F. Robustness Checks: Alternative Definitions of Income Inequality}

For robustness purposes, columns (3) to (6) repeat the baseline estimates by making use of alternative measures of income inequality (recommended by Frank, 2014). These measures are the Atkinson inequality measure and the Theil index. These results provide empirical support to those in columns (1) and (2). 
Table 5.

\section{GMM Estimates Between Income Inequality and Financial Vulnerability}

The table shows GMM estimates of the income inequality and financial vulnerability relationship for the entire sample. AR(1) is the first-order test for residual autocorrelation. $\mathrm{AR}(2)$ is the test for autocorrelation of order 2. Hansen is the test for the overidentification check for the validity of instruments. The difference-in-Hansen test checks the exogeneity of the instruments. Figures in parentheses denote $p$-values with ${ }^{* *}$ and ${ }^{* * *}$ denoting statistical significance at the $5 \%$ and $1 \%$ levels, respectively. All estimations were performed with time dummies.

\begin{tabular}{|c|c|c|c|c|c|c|}
\hline \multirow[t]{2}{*}{ Inequality Measure: } & \multicolumn{2}{|c|}{ Gini } & \multicolumn{2}{|c|}{ Atkinson } & \multicolumn{2}{|c|}{ Theil } \\
\hline & (1) & $(2)$ & (3) & (4) & (5) & (6) \\
\hline \multirow[t]{2}{*}{ Constant } & $0.060^{* * *}$ & $0.047^{* *}$ & $0.064^{* *}$ & $0.060^{* *}$ & $0.056^{* *}$ & $0.045^{* *}$ \\
\hline & {$[0.01]$} & {$[0.05]$} & {$[0.02]$} & {$[0.03]$} & {$[0.04]$} & {$[0.04]$} \\
\hline \multirow[t]{2}{*}{$\Delta$ Financial Vulnerability } & $0.068^{* * *}$ & $0.079^{* * *}$ & $0.076^{* * *}$ & $0.087^{* * *}$ & $0.060^{* * *}$ & $0.068^{* * *}$ \\
\hline & {$[0.00]$} & {$[0.00]$} & {$[0.00]$} & {$[0.00]$} & {$[0.00]$} & {$[0.00]$} \\
\hline \multirow[t]{2}{*}{$\Delta$ Per Capita Income } & & $-0.066^{* * *}$ & & $-0.070^{* * *}$ & & $-0.089^{* * *}$ \\
\hline & & {$[0.00]$} & & {$[0.00]$} & & {$[0.00]$} \\
\hline \multirow[t]{2}{*}{$\Delta$ Per Capita Income $(-1)$} & & $-0.045^{* * *}$ & & $-0.043^{* * *}$ & & $-0.035^{* * *}$ \\
\hline & & {$[0.00]$} & & {$[0.00]$} & & {$[0.01]$} \\
\hline \multirow[t]{2}{*}{$\Delta$ Enrollment Ratio } & & $-0.064^{* * *}$ & & $-0.073^{* * *}$ & & $-0.070^{* * *}$ \\
\hline & & {$[0.00]$} & & {$[0.00]$} & & {$[0.00]$} \\
\hline \multirow[t]{2}{*}{ Polity Index } & & $-0.057^{* * *}$ & & $-0.064^{* * *}$ & & $-0.097^{* * *}$ \\
\hline & & {$[0.00]$} & & {$[0.00]$} & & {$[0.00]$} \\
\hline \multirow[t]{2}{*}{$\Delta$ Corruption } & & $0.050^{* * *}$ & & $0.061^{* * *}$ & & $0.092^{* * *}$ \\
\hline & & {$[0.00]$} & & {$[0.00]$} & & {$[0.00]$} \\
\hline \multirow[t]{2}{*}{$\Delta$ Corruption(-1) } & & $0.038^{* *}$ & & $0.045^{* * *}$ & & $0.058^{* * *}$ \\
\hline & & {$[0.03]$} & & {$[0.01]$} & & {$[0.00]$} \\
\hline \multirow[t]{2}{*}{$\Delta$ Population } & & $-0.045^{* * *}$ & & $-0.053^{* * *}$ & & $0.0492^{* * *}$ \\
\hline & & {$[0.00]$} & & {$[0.00]$} & & {$[0.00]$} \\
\hline \multirow[t]{2}{*}{$\Delta$ Population(-1) } & & $-0.031^{* * *}$ & & $-0.040^{* * *}$ & & $0.024^{* *}$ \\
\hline & & {$[0.01]$} & & {$[0.00]$} & & {$[0.05]$} \\
\hline \multirow[t]{2}{*}{$\Delta$ Government Expenses } & & $-0.106^{* * *}$ & & $-0.114^{* * *}$ & & $-0.095^{* * *}$ \\
\hline & & {$[0.00]$} & & {$[0.00]$} & & {$[0.00]$} \\
\hline \multirow[t]{2}{*}{$\Delta$ Government Expenses(-1) } & & $-0.054^{* * *}$ & & $-0.062^{* * *}$ & & $-0.068^{* * *}$ \\
\hline & & {$[0.00]$} & & {$[0.00]$} & & {$[0.00]$} \\
\hline \multirow[t]{2}{*}{$\Delta$ Government Expenses(-2) } & & $-0.030^{* *}$ & & $-0.038^{* * *}$ & & $-0.042^{* * *}$ \\
\hline & & {$[0.03]$} & & {$[0.01]$} & & {$[0.01]$} \\
\hline \multicolumn{7}{|l|}{ Diagnostic tests } \\
\hline $\mathrm{R}^{2}$ & 0.38 & 0.56 & 0.46 & 0.62 & 0.49 & 0.60 \\
\hline $\mathrm{AR}(1)$ & {$[0.00]$} & {$[0.00]$} & {$[0.00]$} & {$[0.00]$} & {$[0.00]$} & {$[0.00]$} \\
\hline $\operatorname{AR}(2)$ & {$[0.39]$} & {$[0.35]$} & {$[0.50]$} & [0.41] & {$[0.32]$} & {$[0.28]$} \\
\hline Hansen test & {$[0.41]$} & {$[0.45]$} & {$[0.45]$} & {$[0.51]$} & {$[0.36]$} & {$[0.43]$} \\
\hline Difference Hansen test & {$[0.51]$} & {$[0.60]$} & [0.59] & {$[0.58]$} & [0.39] & {$[0.50]$} \\
\hline No. of observations & 884 & 884 & 884 & 884 & 884 & 884 \\
\hline
\end{tabular}


G. Robustness Checks: The Role of the 2007-2008 Crisis in the Nexus of Income Inequality and Financial Vulnerability

The final section explores the role of the 2007-2008 financial crisis. According to Gorton and Ordonez (2014), the advent of the financial crisis brought a substantial increase in financial vulnerability (Ferguson et al., 2007; Reinhart and Rogoff, 2009; Gorton and Ordonez, 2014; Aikman et al., 2017); financial crises adversely affect economic growth, principally due to the decline in investments within an environment of lower credit access. At the same time, the austerity measures taken by governments have negative social impacts, especially on income inequality.

The analysis is repeated prior and after the 2008 event. The new results are presented in Table 6 and they note that while financial vulnerability maintains its negative effect on income equality conditions in both regimes, the impact turns out to be more extended over the second regime (after the crisis event).

Table 6.

\section{GMM Estimates Before and After The 2008 Crisis}

The table shows GMM estimates between income inequality and financial vulnerability (prior and after the 2008 crisis). AR(1) is the first-order test for residual autocorrelation. $\operatorname{AR}(2)$ is the test for autocorrelation of order 2. Hansen is the test for the overidentification check for the validity of instruments. The difference-in-Hansen test checks the exogeneity of the instruments. Figures in parentheses denote $p$-values with ${ }^{* *}$ and ${ }^{* * *}$ denoting statistical significance at the $5 \%$ and $1 \%$ levels, respectively. All estimations were performed with time dummies.

\begin{tabular}{|c|c|c|c|c|c|c|}
\hline \multirow[t]{2}{*}{ Inequality Measure } & \multicolumn{2}{|c|}{ Gini } & \multicolumn{2}{|c|}{ Atkinson } & \multicolumn{2}{|c|}{ Theil } \\
\hline & (1) & (2) & (3) & (4) & (5) & (6) \\
\hline \multicolumn{7}{|l|}{ Prior the 2008 crisis } \\
\hline Constant & $\begin{array}{c}0.081^{* * *} \\
{[0.00]}\end{array}$ & $\begin{array}{c}0.060^{* *} \\
{[0.04]}\end{array}$ & $\begin{array}{c}0.075^{* * *} \\
{[0.00]}\end{array}$ & $\begin{array}{c}0.064^{* *} \\
{[0.02]}\end{array}$ & $\begin{array}{c}0.067^{* * *} \\
{[0.01]}\end{array}$ & $\begin{array}{c}0.054^{* *} \\
{[0.03]}\end{array}$ \\
\hline$\Delta$ Financial Vulnerability & $\begin{array}{c}0.050^{* *} \\
{[0.02]}\end{array}$ & $\begin{array}{c}0.058^{* * *} \\
{[0.01]}\end{array}$ & $\begin{array}{c}0.056^{* *} \\
{[0.02]}\end{array}$ & $\begin{array}{c}0.066^{* * *} \\
{[0.01]}\end{array}$ & $\begin{array}{c}0.044^{* *} \\
{[0.05]}\end{array}$ & $\begin{array}{c}0.053^{* *} \\
{[0.05]}\end{array}$ \\
\hline$\Delta$ Per Capita Income & & $\begin{array}{c}-0.061^{* * *} \\
{[0.00]}\end{array}$ & & $\begin{array}{c}-0.065^{* * *} \\
{[0.00]}\end{array}$ & & $\begin{array}{c}-0.080^{* * * *} \\
{[0.00]}\end{array}$ \\
\hline$\Delta$ Per Capita Income $(-1)$ & & $\begin{array}{c}-0.043^{* * *} \\
{[0.01]}\end{array}$ & & $\begin{array}{c}-0.040^{* * *} \\
{[0.01]}\end{array}$ & & $\begin{array}{c}-0.032^{* *} \\
{[0.04]}\end{array}$ \\
\hline$\Delta$ Enrollment Ratio & & $\begin{array}{c}-0.062^{* * *} \\
{[0.00]}\end{array}$ & & $\begin{array}{c}-0.070^{* * *} \\
{[0.00]}\end{array}$ & & $\begin{array}{c}-0.062^{* * *} \\
{[0.00]}\end{array}$ \\
\hline Polity Index & & $\begin{array}{c}-0.051^{* * * *} \\
{[0.01]}\end{array}$ & & $\begin{array}{c}-0.060^{* * *} \\
{[0.00]}\end{array}$ & & $\begin{array}{c}-0.084^{* * * *} \\
{[0.00]}\end{array}$ \\
\hline$\Delta$ Corruption & & $\begin{array}{c}0.041^{* *} \\
{[0.03]}\end{array}$ & & $\begin{array}{c}0.054^{* * *} \\
{[0.01]}\end{array}$ & & $\begin{array}{c}0.081^{* * * *} \\
{[0.00]}\end{array}$ \\
\hline$\Delta$ Corruption(-1) & & $\begin{array}{c}0.033^{* *} \\
{[0.05]}\end{array}$ & & $\begin{array}{c}0.040^{* *} \\
{[0.03]}\end{array}$ & & $\begin{array}{c}0.051^{* * *} \\
{[0.01]}\end{array}$ \\
\hline$\Delta$ Population & & $\begin{array}{c}-0.040^{* *} \\
{[0.02]}\end{array}$ & & $\begin{array}{c}-0.049^{* * *} \\
{[0.01]}\end{array}$ & & $\begin{array}{c}0.045^{* *} \\
{[0.01]}\end{array}$ \\
\hline$\Delta$ Government Expenses & & $\begin{array}{c}-0.089^{* * *} \\
{[0.00]}\end{array}$ & & $\begin{array}{c}-0.102^{* * *} \\
{[0.00]}\end{array}$ & & $\begin{array}{c}-0.087^{* * * *} \\
{[0.00]}\end{array}$ \\
\hline$\Delta$ Government Expenses(-1) & & $\begin{array}{c}-0.050^{* * * *} \\
{[0.01]}\end{array}$ & & $\begin{array}{c}-0.057^{* * * *} \\
{[0.00]}\end{array}$ & & $\begin{array}{c}-0.061^{* * *} \\
{[0.00]}\end{array}$ \\
\hline
\end{tabular}


Table 6.

GMM Estimates Before and After The 2008 Crisis (Continued)

\begin{tabular}{|c|c|c|c|c|c|c|}
\hline \multirow[t]{2}{*}{ Inequality Measure } & \multicolumn{2}{|c|}{ Gini } & \multicolumn{2}{|c|}{ Atkinson } & \multicolumn{2}{|c|}{ Theil } \\
\hline & (1) & (2) & (3) & (4) & (5) & (6) \\
\hline \multicolumn{7}{|l|}{ Diagnostic tests } \\
\hline $\mathrm{R}^{2}$ & 0.34 & 0.51 & 0.44 & 0.57 & 0.46 & 0.57 \\
\hline $\mathrm{AR}(1)$ & {$[0.00]$} & {$[0.00]$} & {$[0.00]$} & {$[0.00]$} & {$[0.00]$} & {$[0.00]$} \\
\hline $\operatorname{AR}(2)$ & [0.35] & {$[0.30]$} & [0.45] & {$[0.40]$} & {$[0.29]$} & {$[0.26]$} \\
\hline Hansen test & [0.40] & [0.39] & [0.41] & {$[0.48]$} & {$[0.32]$} & [0.35] \\
\hline Difference Hansen test & [0.49] & [0.55] & [0.57] & {$[0.61]$} & {$[0.31]$} & {$[0.47]$} \\
\hline No. of observations & 678 & 678 & 678 & 678 & 678 & 678 \\
\hline \multicolumn{7}{|l|}{ After the 2008 crisis } \\
\hline Constant & $\begin{array}{c}0.069^{* * *} \\
{[0.01]}\end{array}$ & $\begin{array}{l}0.051^{* *} \\
{[0.05]}\end{array}$ & $\begin{array}{c}0.065^{* * *} \\
{[0.01]}\end{array}$ & $\begin{array}{c}0.058^{* *} \\
{[0.03]}\end{array}$ & $\begin{array}{c}0.061^{* *-1} \\
{[0.02]}\end{array}$ & $\begin{array}{c}0.047^{* *} \\
{[0.05]}\end{array}$ \\
\hline$\Delta$ Financial Vulnerability & $\begin{array}{c}0.091^{* * *} \\
{[0.00]}\end{array}$ & $\begin{array}{c}0.104^{* * *} \\
{[0.00]}\end{array}$ & $\begin{array}{c}0.090^{* * *} \\
{[0.00]}\end{array}$ & $\begin{array}{c}0.109^{* * * *} \\
{[0.00]}\end{array}$ & $\begin{array}{c}0.081^{* * *} \\
{[0.00]}\end{array}$ & $\begin{array}{c}0.103^{* * * *} \\
{[0.00]}\end{array}$ \\
\hline$\Delta$ Per Capita Income & & $\begin{array}{c}-0.072^{* * *} \\
{[0.00]}\end{array}$ & & $\begin{array}{c}-0.077^{* * *} \\
{[0.00]}\end{array}$ & & $\begin{array}{c}-0.094^{* * *} \\
{[0.00]}\end{array}$ \\
\hline$\Delta$ Per Capita Income(-1) & & $\begin{array}{c}-0.053^{* * * *} \\
{[0.00]}\end{array}$ & & $\begin{array}{c}-0.051^{* * * *} \\
{[0.00]}\end{array}$ & & $\begin{array}{c}-0.042^{* * *} \\
{[0.00]}\end{array}$ \\
\hline$\Delta$ Enrollment Ratio & & $\begin{array}{c}-0.067^{* * * *} \\
{[0.00]}\end{array}$ & & $\begin{array}{c}-0.071^{* * *} \\
{[0.00]}\end{array}$ & & $\begin{array}{c}-0.072^{* * *} \\
{[0.00]}\end{array}$ \\
\hline Polity Index & & $\begin{array}{c}-0.061^{* * *} \\
{[0.00]}\end{array}$ & & $\begin{array}{c}-0.062^{* * * *} \\
{[0.00]}\end{array}$ & & $\begin{array}{c}-0.112^{* * *} \\
{[0.00]}\end{array}$ \\
\hline$\Delta$ Corruption & & $\begin{array}{c}0.052^{* * *} \\
{[0.00]}\end{array}$ & & $\begin{array}{c}0.064^{* * *} \\
{[0.00]}\end{array}$ & & $\begin{array}{c}0.101^{* * *} \\
{[0.00]}\end{array}$ \\
\hline$\Delta$ Corruption(-1) & & $\begin{array}{c}0.042^{* * *} \\
{[0.01]}\end{array}$ & & $\begin{array}{c}0.052^{* * *} \\
{[0.01]}\end{array}$ & & $\begin{array}{c}0.064^{* * *} \\
{[0.00]}\end{array}$ \\
\hline$\Delta$ Population & & $\begin{array}{c}-0.048^{* * *} \\
{[0.00]}\end{array}$ & & $\begin{array}{c}-0.059^{* * * *} \\
{[0.00]}\end{array}$ & & $\begin{array}{c}0.052^{* * *} \\
{[0.00]}\end{array}$ \\
\hline$\Delta$ Population(-1) & & $\begin{array}{c}-0.040^{* * * *} \\
{[0.01]}\end{array}$ & & $\begin{array}{c}-0.042^{* * * *} \\
{[0.00]}\end{array}$ & & $\begin{array}{c}0.036^{* *} \\
{[0.03]}\end{array}$ \\
\hline$\Delta$ Government Expenses & & $\begin{array}{c}-0.119^{* * * *} \\
{[0.00]}\end{array}$ & & $\begin{array}{c}-0.125^{* * *} \\
{[0.00]}\end{array}$ & & $\begin{array}{c}-0.107^{* * *} \\
{[0.00]}\end{array}$ \\
\hline$\Delta$ Government Expenses(-1) & & $\begin{array}{c}-0.061^{* * *} \\
{[0.00]}\end{array}$ & & $\begin{array}{c}-0.067^{* * * *} \\
{[0.00]}\end{array}$ & & $\begin{array}{c}-0.072^{* * *} \\
{[0.00]}\end{array}$ \\
\hline$\Delta$ Government Expenses(-2) & & $\begin{array}{c}-0.035^{* *} \\
{[0.02]}\end{array}$ & & $\begin{array}{c}-0.044^{* * * *} \\
{[0.00]}\end{array}$ & & $\begin{array}{c}-0.053^{* * *} \\
{[0.00]}\end{array}$ \\
\hline Diagnostic tests & & & & & & \\
\hline $\mathrm{R}^{2}$ & 0.38 & 0.52 & 0.44 & 0.57 & 0.51 & 0.6 \\
\hline $\mathrm{AR}(1)$ & {$[0.00]$} & {$[0.00]$} & {$[0.00]$} & {$[0.00]$} & {$[0.00]$} & {$[0.00]$} \\
\hline $\operatorname{AR}(2)$ & {$[0.45]$} & {$[0.42]$} & {$[0.54]$} & {$[0.45]$} & {$[0.36]$} & {$[0.37]$} \\
\hline Hansen test & {$[0.46]$} & {$[0.50]$} & {$[0.52]$} & {$[0.56]$} & {$[0.39]$} & {$[0.45]$} \\
\hline Difference Hansen test & [0.53] & [0.59] & {$[0.58]$} & {$[0.63]$} & {$[0.44]$} & {$[0.52]$} \\
\hline No. of observations & 206 & 206 & 206 & 206 & 206 & 206 \\
\hline
\end{tabular}




\section{CONCLUSION}

This paper provided a study concerning the impact of financial vulnerability on income inequality. With the use of a panel of OECD countries and the methodologies of panel GARCH and GMM approaches the results documented that financial vulnerability exerted a negative impact on income inequality. The results survived alternative income inequality, while they highlighted the impact of the Global Financial Crisis by documenting that the role of financial vulnerability in the income inequality process was enhanced over the crisis regime.

Financial vulnerability adds a new risk-taking channel. This new venue of the transmission mechanism can significantly affect income inequality issues, and this raises the importance of the role of regulators and policy makers to efficiently monitor financial intermediation, as well as financial markets.

\section{REFERENCES}

Acemoglu, D., Naidu, S., Restrepo, P., \& Robinson, J.A. (2015). Democracy, Redistribution and Inequality. In: Atkinson, A.B., \& Bourguignon, F. (Eds.) Handbook of Income Distribution, Vol 2. Elsevier, North-Holland.

Adrian, T., \& Duarte, F. (2016). Financial Vulnerability and Monetary Policy. Federal Reserve Bank of New York Staff Reports, No. 804.

Adrian, T., \& Liang, N. (2017). Monetary Policy, Financial Conditions, and Financial Stability. International Journal of Central Banking, 10, 95-135.

Adrian, T., \& Shin, H. (2010). Financial Intermediaries and Monetary Economics. Handbook of Monetary Economics, 3, 601-650.

Adrian, T., Boyarchenko, N., \& Giannone, D. (2016). Vulnerable Growth. Federal Reserve Bank of New York Staff Reports, No. 794.

Adrian, T., Covitz, D., \& Liang, N. (2015). Financial Stability Monitoring. Annual Review of Financial Economics, 7, 357-395.

Aikman, D., Kiley, M., Lee, S.J., Palumbo, M.G., \& Warusawitharana, M. (2017). Mapping Heat in the U.S. Financial System. Journal of Banking and Finance, 81, 36-64.

Arellano, M., \& Bond, S. (1991). Some Tests of Specification for Panel Data: Monte Carlo Evidence and an Application to Employment Equations. Review of Economic Studies 58, 277-297.

Christofi, A., \& Pericli, A. (1999). Correlation in Price Changes and Volatility of Major Latin American Stock Markets. Journal of Multinational Financial Management, 9, 79-93.

Duarte, F., \& Rosa, C. (2013). Are Stocks Cheap? A Review of Evidence. Liberty Street Economics, May 08.

Er, Ș., \& Fidan, N. (2013). Modeling Istanbul Stock Exchange-100 Daily Stock Returns: A Nonparametric GARCH Approach. Journal of Business, Economics and Finance, 2, 36-50.

Estrella, A., \& Hardouvelis, G.A. (1991). The Term Structure as a Predictor of Real Economic Activity. Journal of Finance, 46, 555-576.

Estrella, A., \& Mishkin, F.S. (1998). Predicting US Recessions: Financial Variables as Leading Indicators. Review of Economics and Statistics, 80, 45-61. 
Ferguson, R.W., Hartmann, P., Panetta, F., \& Portes, R. (2007). International Financial Stability, Geneva Report on the World Economy. Center for Economic Policy Research.

Frank, M.W. (2014). A New State-Level Panel of Annual Inequality Measures Over the Period 1916-2005. Journal of Business Strategies, 31, 241-263.

Gambacorta, L., \& Signoretti, F.M. (2014). Should Monetary Policy Lean Against the Wind? An Analysis Based on a DSGE Model with Banking. Journal of Economic Dynamics and Control, 43, 146-174.

Gilchrist, S., \& Zakrajsek, E. (2012). Credit Spreads and Business Cycle Fluctuations. American Economic Review, 102, 1692-1720.

Gorton, G., \& Ordonez, G. (2014). Collateral Crises. American Economic Review, 104, 343-378.

Gupta, S., Davoodi, H., \& Alonso-Terme, R. (2002). Does Corruption Affect Income Inequality and Poverty? Economics of Governance, 3, 23-45.

Jalilian, H., \& Kirkpatrick, C. (2002). Financial Development and Poverty Reduction in Developing Countries. International Journal of Financial Economics, 7, 97-108.

Kai, H., \& Hamori, S. (2009). Globalization, Financial Depth, and Inequality in Sub-Saharan Africa. Economic Bulletin, 29, 2025-2037.

Krishnamurthy, A., \& Muir, T. (2016). Credit Cycles Across a Financial Crisis. Unpublished paper, Stanford University.

Liu, G. (2012). Improving the Local Financial Management System. Chinese Finance, $15,82-83$.

Lopez-Salido, D., Stein, J. C., \& Zakrajsek, E. (2017). Credit-Market Sentiment and the Business Cycle. The Quarterly Journal of Economics, 132, 1373-1426.

Mallick, S.K., \& Sousa, R.M. (2013). The Real Effects of Financial Stress in the Eurozone. International Review of Financial Analysis, 30, 1-17.

Marshall, M., \& Jaggers, K. (2015). Polity IV project. Available at: http://www. systemicpeace.org/polity/polity15.htm\#nam.

Mauro, P. (1997). The Effects of Corruption on Growth, Investment, and Government Expenditure: A Cross-Country Analysis. In: Elliott, K.A. (Ed.) Corruption and the Global Economy, 83-107. Institute for International Economics, Washington D.C.

Minsky, H. (1982). The Financial Fragility Hypothesis: Capitalist Process and the Behavior of the Economy. In Kindleberger, C.P. and Laffargue, J.P. (Eds.). Financial Crises. Cambridge: Cambridge University Press.

Neumayer, E. (2003a). Do Human Rights Matter in Bilateral Aid Allocation? A Quantitative Analysis of 21 Donor Countries. Social Science Quarterly, 84, 650666.

Neumayer, E. (2003b). Is Respect For Human Rights Rewarded? An Analysis of Total Bilateral and Multilateral Trade Flows. Human Rights Quarterly, 25, 510527.

Nikkinen, J., Omran, M.M., Sahlström, P., \& Äijö, J. (2008). Stock Returns and Volatility Following the September 11 Attacks: Evidence from 53 Equity Markets. International Review of Financial Analysis, 17, 27-46.

Pesaran, M. (2007). A Simple Panel Unit Root Test in the Presence of Cross-Section Dependence. Journal of Applied Econometrics, 22, 265-312. 
Philippon, T. (2009). The Bond Market's Q. The Quarterly Journal of Economics, 124, 1011-1056.

Roberts, J. (2003). Poverty Reduction Outcomes in Education and Health Public Expenditure and Aid. Overseas Development Institute, Working Paper, No. 210.

Rodrik, D. (1996). Labor Standards in International Trade: Do They Matter and What Do We Do About Them? In Lawrence, R.Z., Rodrik, D., \& Whalley, J. (Eds.), Emerging Agenda for Global Trade: High Stakes for Developing Countries, 35-80, Washington, DC: Johns Hopkins University Press.

Rose-Ackerman, S. (1999). Corruption and Government: Causes, Consequences and Reform. Cambridge University Press, Cambridge.

Shin, J. (2005). Stock Returns and Volatility in Emerging Stock Markets. International Journal of Business and Economics, 4, 31-43.

Smith, V., Leybourne, S., \& Kim, T.H. (2004). More Powerful Panel Unit Root Tests with an Application to the Mean Reversion in Real Exchange Rates. Journal of Applied Econometrics, 19, 147-170.

Svensson, L.E. (2016a). Cost-Benefit Analysis of Leaning Against the Wind: Are Costs Larger Also with Less Effective Macroprudential Policy? National Bureau of Economic Research, Working Paper, No. 21902.

Svensson, L.E. (2016b). Inflation Targeting and 'Leaning Against the Wind'. Israel Economic Review, 13, 91-99.

Tropeano, D. (2013). Financial Fragility in the Current European Crisis. CITYPERC Working Paper Series, No. 09. 


\section{Appendix A \\ List of Countries.}

Australia, Austria, Belgium, Canada, Chile, Czech Republic, Denmark, Estonia, Finland, France, Germany, Greece, Hungary, Iceland, Ireland, Israel, Italy, Japan, Korea, Latvia, Luxembourg, Mexico, Netherlands, New Zealand, Norway, Poland, Portugal, Slovak Republic, Spain, Sweden, Switzerland, Turkey, U.K., U.S.

\section{Appendix B.}

$$
\begin{aligned}
& d y_{t}=\sigma^{-1}\left(i_{t}-\pi_{t}\right) d t+d\left(\operatorname{erp}_{t}\right) \\
& d\left(\operatorname{erp}_{t}\right)=-\varrho V_{t} d t+\xi\left(V_{t}-x_{t}\right) d Z_{t} \\
& d x_{t}=Q_{x}\left(\mu_{x}-x_{t}\right) d t+\sigma_{x} d Z_{x, t} \\
& d \pi_{t}=\left(\beta \pi_{t}-k y_{t}\right) d t
\end{aligned}
$$

$\mathrm{y}$ is GDP, $\pi$ stands for inflation, $\mathrm{i}$ is the central bank interest rate, erp is the equity risk premium. The vulnerability determines the conditional mean $-\mathrm{eV}$ and the conditional volatility $\xi\left(V_{t}-x_{t}\right)$ of the risk premium. Shocks $d Z t$ and $d Z x, t$ are not correlated to each other, $x_{t}$ is the shock to volatility (following a mean reverting process). $\mathrm{Q}$ is the mean reversion for the equity premium. Equation (B1) is the IS curve, plus a risk premium, Equation (B2) illustrates that the risk premium depends on vulnerability $\mathrm{V}_{\mathrm{t}}$. Equation (B3) describes the path of shocks in the economy. Finally, Equation (B4) is the Phillips curve. They also minimize a quadratic loss function:

$$
L\left(y_{t}, \pi_{t}\right)=\min E_{t} \int_{t}^{\infty} e^{-t \beta}\left(y_{t}^{2}+\pi_{t}^{2}\right) d t
$$

subject to the restrictions describes in equations (B1)-(B4). They also provide the quadratic solution which yields:

$L(y ; \pi ; x)=c_{0}+c_{1} y+c_{2} y^{2}+c_{3} x+c_{4} x^{2}+c_{5} y x+c_{6} \pi+c_{7} \pi^{2}+c_{8} y \pi+c_{9} \pi x$

And, thus, they provide the vulnerability index:

$\mathrm{FV}_{\mathrm{t}}=\left[(1-\gamma \xi) / \xi^{2}\right] \mathrm{y}_{\mathrm{t}}+\left[(1-\gamma \xi) \mathrm{c}_{8}\right] /\left[2 \xi^{2} \mathrm{c}_{2}\right] \pi_{\mathrm{t}}+\left[1-(\gamma \xi-1) / 2 \xi^{2}\right]\left[\mathrm{c}_{5} / \mathrm{c}_{2}\right] \mathrm{x}_{\mathrm{t}}+$ $\left[(1-\gamma \xi) / 2 \xi^{2}\right]\left[c_{1} / c_{2}\right]$ 
where:

$$
\begin{aligned}
c_{1}= & {\left[2 \xi^{2} \mu_{x} Q_{x} /(1-\gamma \xi)^{2}\right]\left[c_{2} c_{9} / c_{8}\right] } \\
c_{2}= & \left\{\left[4 c_{6} \xi^{2} k^{2} /(1-\gamma \xi)^{2}\right]+\left[2(1-\gamma \xi)^{2} / \xi^{2}\right]\right\}^{-1} \\
c_{5}= & {\left[-2 c_{2} / k+1 / Q_{x}\left(1 / k-1 / k\left(\beta+(1-\gamma \xi)^{2} / \xi^{2}\right) c_{2}\right)\right] x } \\
& {\left[\left(-(1-\gamma \xi)^{2} / 2 \xi^{2} Q_{x}\right)\left(1 / k c_{2}-1 / k\left(\beta+(1-\gamma \xi)^{2} / \xi^{2}\right)\right)+1 / k\left(\beta+Q_{x}+(1-\gamma \xi)^{2} / \xi^{2}\right)^{-1}\right.} \\
c_{6}= & -1 / k c_{1}\left[\beta+(1-\gamma \xi)^{2} / \xi^{2}\right]+\mu_{x} Q_{x} c_{5} / k \\
c_{8}= & 1 / k-1 / k\left(\beta+(1-\gamma \xi)^{2} / \xi^{2}\right) c_{2} \\
c_{9}= & -2 / k c_{2}-1 / k\left(\beta+Q_{x}+(1-\gamma \xi)^{2} / \xi^{2}\right) c_{5}
\end{aligned}
$$

